\title{
Multi-Objective Optimization of Machining Parameters for Multi- Pass CNC Turning to Minimize Carbon Emissions, Energy, Noise and Cost
}

\author{
Bening Maulina Fittamami ${ }^{*}$, Eko Pujiyanto ${ }^{1}$, Yusuf Priyandari ${ }^{1}$
}

\begin{abstract}
Global warming is a huge environmental issue today. This is due to the high level of world carbon emissions. The manufacturing process accounts for $30 \%$ of the world's carbon emissions production. Sustainable manufacturing is necessary to implement to reduce carbon emission levels caused by the manufacturing process. There are three aspects of sustainable manufacturing, namely environmental aspects, economic aspects, and social aspects. These three aspects can be implemented in the machining process by optimizing machining parameters in multi-pass $\mathrm{CNC}$ turning. This research aims to optimize $\mathrm{CNC}$ turning machining parameters by considering energy consumption, carbon emissions, noise, and production cost. The model is solved using a Multi-objective Genetic Algorithm in Matlab 2016b then the transformation and weighting functions are carried out from the feasible value. Based on the optimization results, the total energy consumption value obtained is $2.50 \mathrm{MJ}$; total production cost is $\$ 2.19$; total carbon emissions are $5.97 \mathrm{kgCO} 2$, and noise is $236,19 \mathrm{~dB}$. The sensitivity analysis exhibits the machining parameters that affect the objective function: The cutting speed parameter and the feed rate parameter. This model can be used to improve the manufacturing process and support sustainable manufacturing.
\end{abstract}

Keywords: Sustainable manufacturing, multi-objective optimization, energy, cost, carbon emissions, noise.

\section{Introduction}

The manufacturing industry plays a vital role in the global economy. However, it also causes various problems due to energy consumption, environmental sustainability, and personal health [1]. For example, the manufacturing industry sector accounts for $50 \%$ of total energy consumption [2]. Global warming is the most significant environmental issue today due to high carbon emissions. The manufacturing process accounts for $30 \%$ of the world's carbon emissions. Energy consumption in manufacturing has increased twofold over the past 60 years, and the number continues to grow [3].

Global warming has prompted the formation of policies related to the earth's climate change. Kyoto Protocol is one of the policies issued by the UNFCCC [4] in 1990. The aim of the Kyoto Protocol is to reduce carbon emissions of each country by 52\% from 1990 levels. Several countries have implemented carbon emission taxes as a form of commitment to the Kyoto Protocol. Due to this policy, the manufacturing indus

${ }^{1}$ Faculty of Engineering, Department of Industrial Engineering, Universitas Sebelas Maret, J. Ir. Sutama, Surakarta 57126, Indonesia. Email: beningmaulina@gmail.com,

ekopujiyanto@staff.uns.ac.id, priyandari@staff.uns.ac.id

* Corresponding author try has new challenges to reduce production costs. Therefore, the manufacturing industry needs to adapt by implementing sustainable manufacturing. Sustainable manufacturing is creating manufactured products to minimize negative impacts on the environment, energy-saving, and natural resources, and are safe for employees, society, and consumers. There are three aspects of sustainable manufacturing: economic, environmental, and social [5]. This research developed an optimization model of multipass CNC turning by considering energy consumption, carbon emissions, production cost, and noise.

Previous research such as $[6,7,8,9]$ stated that machining parameters such as cutting speed, feed rate, and depth of cut can affect the energy and costs incurred during machining. Arif, et al. [10] developed an energy optimization model consisting of machining, idle, tool replacement, and cutting tool energy. Chen and Tsai [11] minimized the production cost per unit with machining components, machine idle, tool replacement, and tool costs. The carbon emissions model uses the model proposed by Li et al. [3], total carbon emissions consist of electricity, cutting tool chip carbon emissions, cutting fluid carbon emissions, and material chip carbon emissions, cutting fluid carbon emissions, and material carbon emissions. The development of the noise model is based on the research conducted by Cirtu 
Table 1. Research position

\begin{tabular}{|c|c|c|c|c|c|c|c|c|c|c|c|c|}
\hline \multirow[t]{2}{*}{ Authors } & \multirow{2}{*}{$\begin{array}{l}\text { Machining } \\
\text { Process }\end{array}$} & \multicolumn{5}{|c|}{ Machining Parameters } & \multicolumn{6}{|c|}{ Objective Functions } \\
\hline & & $\begin{array}{l}\text { Cutting } \\
\text { speed }\end{array}$ & $\begin{array}{l}\text { Feed } \\
\text { rate }\end{array}$ & $\begin{array}{l}\text { Depth } \\
\text { of cut }\end{array}$ & $\begin{array}{c}\text { Roughing } \\
\text { pass }\end{array}$ & $\begin{array}{l}\text { Tool } \\
\text { wear }\end{array}$ & $\begin{array}{c}\text { Carbon } \\
\text { emission }\end{array}$ & $\begin{array}{c}\text { Energy } \\
\text { consumption }\end{array}$ & Cost & Noise & $\begin{array}{c}\text { Processing } \\
\text { time }\end{array}$ & Quality \\
\hline $\begin{array}{l}\text { Chen \& } \\
\text { Tsai [11] }\end{array}$ & $\begin{array}{l}\text { Multi-pass } \\
\text { turning }\end{array}$ & $\mathrm{v}$ & $\mathrm{v}$ & $\mathrm{v}$ & & & & & $\mathrm{v}$ & & & \\
\hline $\begin{array}{l}\text { Arif, et al. } \\
{[10]}\end{array}$ & $\begin{array}{l}\text { Multi-pass } \\
\text { turning }\end{array}$ & $\mathrm{v}$ & $\mathrm{v}$ & $\mathrm{v}$ & $\mathrm{v}$ & & & $\mathrm{v}$ & & & & \\
\hline $\mathrm{Li}$, et al. [3] & $\begin{array}{l}\text { Single-pass } \\
\text { turning }\end{array}$ & $\mathrm{v}$ & $\mathrm{v}$ & $\mathrm{v}$ & & & $\mathrm{v}$ & & & & & \\
\hline $\begin{array}{l}\text { Zhang, et } \\
\text { al. [1] }\end{array}$ & $\begin{array}{l}\text { Single-pass } \\
\text { turning }\end{array}$ & $\mathrm{v}$ & $\mathrm{v}$ & $\mathrm{v}$ & & & & $\mathrm{v}$ & $\mathrm{v}$ & $\mathrm{v}$ & & \\
\hline Lu, et al. [5] & $\begin{array}{l}\text { Multi-pass } \\
\text { turning }\end{array}$ & $\mathrm{v}$ & $\mathrm{v}$ & $\mathrm{v}$ & $\mathrm{v}$ & & & $\mathrm{v}$ & & & & $\mathrm{v}$ \\
\hline $\begin{array}{l}\text { Tian, et al. } \\
{[18]}\end{array}$ & $\begin{array}{l}\text { Turning, } \\
\text { milling dan } \\
\text { drilling }\end{array}$ & $\mathrm{v}$ & $\mathrm{v}$ & $\mathrm{v}$ & & $\mathrm{v}$ & $\mathrm{v}$ & $\mathrm{v}$ & & & & \\
\hline $\begin{array}{l}\text { Bagaber } \\
\text { \&Yusoff [7] }\end{array}$ & $\begin{array}{l}\text { Single-pass } \\
\text { turning }\end{array}$ & $\mathrm{v}$ & $\mathrm{v}$ & $\mathrm{v}$ & & & & $\mathrm{v}$ & $\mathrm{v}$ & & & $\mathrm{v}$ \\
\hline $\begin{array}{l}\text { Citru, et al. } \\
{[12]}\end{array}$ & $\begin{array}{l}\text { Turning, } \\
\text { milling dan } \\
\text { drilling }\end{array}$ & $\mathrm{v}$ & $\mathrm{v}$ & & & & & & & $\mathrm{v}$ & & \\
\hline $\begin{array}{l}\text { Addona \& } \\
\text { Teti [17] }\end{array}$ & $\begin{array}{l}\text { Single-pass } \\
\text { turning }\end{array}$ & $\mathrm{v}$ & $\mathrm{v}$ & $\mathrm{v}$ & & & & & $\mathrm{v}$ & & $\mathrm{v}$ & $\mathrm{v}$ \\
\hline $\begin{array}{l}\text { This } \\
\text { research }\end{array}$ & $\begin{array}{l}\text { Multi-pass } \\
\text { turning }\end{array}$ & $\mathrm{v}$ & $\mathrm{v}$ & $\mathrm{v}$ & & & $\mathrm{v}$ & $\mathrm{v}$ & $\mathrm{v}$ & $\mathrm{v}$ & & \\
\hline
\end{tabular}

[12] on the measurement of noise levels in all types of the cutting tool.

This research develops three aspects of sustainable manufacturing that are applied to the CNC Turning multi-pass machine. These three aspects will be converted into a mathematical model. The optimization model development for multi-pass CNC turning aims to minimize energy consumption, carbon emissions, noise, and production cost. The decision variables used in this research are roughing cutting speed, finishing cutting speed, roughing feed rate, finishing feed rate, depth of roughing cut, and depth of finishing cut.

\section{Methods}

The method used in this research is a Genetic Algorithm. A Genetic Algorithm is a computational algorithm that can be used to solve the search for optimal solutions in a more natural optimization [13, 14]. In this method, the solution step begins with coding to represent the real problem into biological terminology. Then, individuals who can proceed to reproduction were selected. A Crossbreeding is used to produce children from two chromosomes and mutations to make changes to a gene or individual [15]. The mathematical model of the objective function of energy consumption, carbon emissions, noise, and the production cost was optimized using the Genetic Algorithm Method in the MATLAB R2016b software with two times the amount of rough. From this method, a feasible solution is obtained for the optimization of the objective function.

Furthermore, the results of the feasible solution were processed using the transformation function method. Problems with multi-objective optimization can be solved using a transformation function [16]. The transformation function is used to equalize the different units into dimensionless units. After obtaining a dimensionless value, the Weighted Sum Method was applied. The WSM score is obtained by multiplying the given weight score by the objective function score [17]. The amount of weight was adjusted to the decision maker's preference, which represents the relative importance of the objective function. Here is an equation of the Weighted Sum Method (WSM).

$U=\sum_{i=1}^{k} w_{i} F_{i}(x)$

\section{Decision Variable}

The object of this research is multi-pass machining of CNC Turning, which will be optimized by considering energy consumption, carbon emission, noise, and production cost. The decision variables of this study are cutting speed of roughing, cutting speed of finishing, roughing feed rate, finishing feed rate, depth of cut in roughing, and depth of cut in finishing (see Table 1 as a comparison).

$\begin{array}{lll}\begin{array}{l}\text { List of Notations } \\ C E_{\text {elec }}\end{array} & : \begin{array}{l}\text { Electricity carbon emissions } \\ \left(\mathrm{kgCO}_{2}\right)\end{array} \\ C E_{\text {tool }} & : & \begin{array}{l}\text { Cutting tool carbon emissions } \\ \left(\mathrm{kgCO}_{2}\right)\end{array} \\ C E F_{\text {elec }} & : & \text { Electricity carbon emission factor } \\ & & (\mathrm{kgCO} / \mathrm{kWh}) \\ C E F_{\text {tool }} & : & \text { Cutting tool carbon emissions } \\ & & \text { factor }(\mathrm{kgCO} / \mathrm{kWh}) \\ C_{m} & : & \text { Machining cost }(\$) \\ C_{i} & : & \text { Machine idle cost }(\$) \\ C_{t r} & : & \text { Tool replacement cost }(\$) \\ C_{t w} & : & \text { Tool cost }(\$) \\ E_{c} & : & \text { Machining energy }(\mathrm{MJ}) \\ E_{i} & : & \text { Idle energy }(\mathrm{MJ})\end{array}$




\begin{tabular}{|c|c|}
\hline$E_{r}$ & : Tool replacement energy (MJ) \\
\hline$E_{T}$ & : Tool energy (MJ) \\
\hline$D$ & : Diameter of workpiece $(\mathrm{mm})$ \\
\hline$L$ & : Length of workpiece(mm) \\
\hline$C_{a}, p, q, r$ & : Constant related tool life \\
\hline$a_{p r} r_{\max }$ & $\begin{array}{l}\text { Upper bound of depth of rough cut } \\
(\mathrm{mm})\end{array}$ \\
\hline apr $\min$ & $\begin{array}{l}\text { Lower bound of depth of rough cut } \\
(\mathrm{mm})\end{array}$ \\
\hline apsmax & $\begin{array}{l}\text { Upper bound of depth of finish cut } \\
(\mathrm{mm})\end{array}$ \\
\hline aps $\min$ & $\begin{array}{l}\text { Lower bound of depth of finish cut } \\
(\mathrm{mm})\end{array}$ \\
\hline$f r_{\max }$ & $\begin{array}{l}\text { : Upper bound of feed rate in rough } \\
\text { machining }(\mathrm{mm})\end{array}$ \\
\hline$f r_{\min }$ & $\begin{array}{l}\text { Lower bound of feed rate in rough } \\
\text { machining }(\mathrm{mm})\end{array}$ \\
\hline$f s_{\max }$ & $\begin{array}{l}\text { Upper bound of feed rate in finish } \\
\text { machining }(\mathrm{mm})\end{array}$ \\
\hline$f s_{\min }$ & $\begin{array}{l}\text { Lower bound of feed rate in finish } \\
\text { machining }\end{array}$ \\
\hline$v r_{\max }$ & $\begin{array}{l}\text { Upper bound of cutting speed in } \\
\text { rough machining }(\mathrm{m} / \mathrm{min})\end{array}$ \\
\hline$v r_{\min }$ & $\begin{array}{l}\text { Lower bound of cutting speed in } \\
\text { rough machining }(\mathrm{m} / \mathrm{min})\end{array}$ \\
\hline$v s_{\max }$ & $\begin{array}{l}\text { Upper bound of cutting speed in } \\
\text { finish machining }(\mathrm{m} / \mathrm{min})\end{array}$ \\
\hline$v s_{\min }$ & $\begin{array}{l}\text { : Lower bound of cutting speed in } \\
\text { finish machining }(\mathrm{m} / \mathrm{min})\end{array}$ \\
\hline$h_{1}, h_{2}$ & $\begin{array}{l}\text { Constants pertaiing to tool travel } \\
\text { and approach/depart time (min) }\end{array}$ \\
\hline$k$ & : Specific cutting energy $\left(\mathrm{J} / \mathrm{m}^{3}\right)$ \\
\hline$k_{0}$ & $\begin{array}{l}\text { Direct labor cost and overhead } \\
(\$ / \mathrm{min})\end{array}$ \\
\hline$k_{t}$ & : Cutting edge cost (\$/edge) \\
\hline$k_{1}, k_{2}, k_{3}$ & $\begin{array}{l}\text { : Constants for roufhinf and } \\
\text { finishing parameter relations }\end{array}$ \\
\hline$k_{q}$ & $\begin{array}{l}\text { Chip tool interface temperature } \\
\text { constraint }\end{array}$ \\
\hline$k_{f}$ & : Constraint in surface roughness \\
\hline Po & : Idle power $(\mathrm{kWh})$ \\
\hline$P t$ & : Tool power (MJ/insert) \\
\hline$R r_{\max }$ & $\begin{array}{l}\text { Upper bound of surface roughness } \\
\text { roughing }(\mu \mathrm{m})\end{array}$ \\
\hline$R s_{\max }$ & $\begin{array}{l}\text { Upper bound of surface roughness } \\
\text { finishing }(\mu \mathrm{m})\end{array}$ \\
\hline re & : Nose radius of tool $(\mathrm{mm})$ \\
\hline$V$ & $\begin{array}{l}\text { Volume rate of material removal } \\
\left(\mathrm{m}^{3} / \mathrm{min}\right)\end{array}$ \\
\hline te & : Tool replacement time (min/edge) \\
\hline$t p$ & : Preparation time (min/unit) \\
\hline $\mathrm{tm}$ & : Machining time (min) \\
\hline$t_{m r}$ & : Machining time of roughing (min) \\
\hline$t_{m s}$ & : Machining time of finishing (min) \\
\hline$t l$ & : Idle time (min) \\
\hline$t c$ & : Variable time (min) \\
\hline
\end{tabular}

\begin{tabular}{|c|c|}
\hline$T$ & $\begin{array}{l}\text { : Tool life of roughing and finishing } \\
\text { (min) }\end{array}$ \\
\hline $\operatorname{Tr}_{i}$ & : Tool life of -i- roughing (min) \\
\hline$T s$ & : Tool life finishing (min) \\
\hline Wtool & : Mass of tool \\
\hline$w$ & : Weight \\
\hline$Q r_{i}$ & $\begin{array}{l}\text { : chip tool interface temperature } \\
\text { during roughing }\left({ }^{\circ} \mathrm{C}\right)\end{array}$ \\
\hline Qs & $\begin{array}{l}\text { chip tool interface temperature } \\
\text { during finishing }\left({ }^{\circ} \mathrm{C}\right)\end{array}$ \\
\hline$Q u$ & $\begin{array}{l}\text { Maximum allowable chip-tool } \\
\text { interface temperature }\left({ }^{\circ} \mathrm{C}\right)\end{array}$ \\
\hline$F r_{i}$ & $\begin{array}{l}\text { Cutting force during roughing } \\
\text { (kgf) }\end{array}$ \\
\hline Fs & : Cutting force during finshing (kgf) \\
\hline$F_{\max }$ & $\begin{array}{l}\text { : Maximum allowable cutting force } \\
\text { (kgf) }\end{array}$ \\
\hline$\delta, \phi, \tau$ & $\begin{array}{l}\text { Constants related to equation of } \\
\text { chip tool interface temperature }\end{array}$ \\
\hline$\mu, \theta$ & : Constants related to cutting force \\
\hline$\eta$ & : Machine efficiency \\
\hline & : Possible value of roughing pass \\
\hline
\end{tabular}

\section{Machining Time}

Machining time is the time used during the machining process. Machining time significantly affects the energy consumption used during machining and the total production cost. Time in the turning process is divided into four types: machining time, idle time, tool wear time, and tool replacement time. The equation for the machining time $(\mathrm{tm})$ is formulated as follows: $t m=t m r+t m s$

$t_{m r}$ is the time needed during roughing and $t_{m s}$ is the time needed during the process. The roughing process was carried out several times. The roughing and finishing time are formulated as follows,

$t m r=\sum_{i=1}^{n} \frac{\pi D L}{1000 r_{i} f r_{i}}$

where, $D$ is diameter workpiece and $L$ is length of workpiece.

$t m s=\frac{\pi D L}{1000 v s s}$

Total machining time $[10,11]$

$t m=\sum_{i=1}^{i=n} \frac{\pi D L}{1000 v r_{i} f r_{i}}+\frac{\pi D L}{1000 v s f s}$

The equation of idle time is divided into two parts, namely the time during loading and unloading operations $\left(t_{p}\right) \cdot t_{p}$ score is constant. $t_{c}$ is the tool idle motion when it approaching/departing the edge of the workpiece. The equation of idle time is provided as follows

$t_{l}=t_{p}+t_{c}$

Equation of idle time when the tool approaches/ arrives at the workpiece $\left(t_{i}\right)$

$t_{c}=n\left(h_{1} L+h_{2}\right)+\left(h_{1} L+h_{2}\right)$ 
Total idle time

$t_{l}=t_{p}+\left(n\left(h_{1} L+h_{2}\right)+\left(h_{1} L+h_{2}\right)\right)$

Tool life equation is expanded using Taylor's equation and can be formulated as follows $v T^{\alpha} f^{\beta} a p^{\gamma}=C$

$T=\frac{C^{1 / \alpha}}{v^{1 / \alpha} f^{\beta / \alpha} a p^{\gamma / \alpha}}=\frac{C_{0}}{v^{p} f^{q} a p^{r}}$

Assumed that the entire machining process used the same tools for roughing $\left(T_{r i}\right)$ and finishing process $\left(T_{s}\right)$. Between roughing and finishing process, there are differs wear rate of tools due to different machining condition. Therefore, $T$ can be contructed as the summation of those two processes.

$T=\theta T_{r i}+(1-\theta) T_{s}$

$T_{r i}=\frac{C a}{v r_{i}^{p} f r_{i}^{q} a_{p r_{i}}^{r}}$

$T_{s}=\frac{C a}{v_{s}^{p} f_{s}^{q} a_{p_{s}}^{r}}$

\section{Energy Consumption}

The total energy consumption (Etotal) in the machining process of multi-pass turning is obtained from the machining energy consumption $\left(E_{c}\right)$, energy consumption when the machine is idle $(E l)$, energy consumption when replacing tools $(E m)$ and energy consumption of tools $(E t)$ based on the optimization model developed by Arif et al.[10].

\section{Energy consumption in machining $\left(E_{c}\right)$}

Energy consumption in machining $\left(E_{c}\right)$ is the energy used during the machining process for material feeding. The amount of energy consumption is determined by idle power, feeding volume, and length of machining time or as formulated as follow.

$E c=(P o+k V) t m$

where, $P o$ denotes idle power, $k$ is the machining specific energy, $V$ is the feeding volume and tm is the machining time.

\section{Energy consumption at idle $(E l)$}

When the machine is idle, the energy required is the same as the energy when there is no spindle rotation. $E l=P o \times t l$

Using equation (8) and (15) the idle time can be writte as

$E l=P o \times\left(t p+\left(n\left(h_{1} L+h_{2}\right)+\left(h_{1} L+h_{2}\right)\right)\right.$

\section{Energy consumption when replacing tool}

The cutting tool is replaced when the engine is running but the spindle is turned off. According to
Shaw [19], the part-by-part tool replacement time is the result of the time of tool replacement per edge with the total edge consumed $\left(t_{m} / T\right)$.

$E m=P o \times t e\left(t_{m} / T\right)$

\section{Cutting tool energy consumption}

According to Shaw [19], the part-by-part tool replacement time is the result of the tool replacement time per edge with the total of the consumed edge.

$E t=P t \times\left(t_{m} / T\right)$

\section{Total carbon emissions}

Total energy is the sum of machining energy, energy when the machine is idle, energy when replacing tools, and cutting tool energy.

$E_{\text {total }}=E c+E l+E m+E t$

The equation for the total energy can be simplified by categorizing it into the total energy during roughing and finishing. They can be formulated as follows:

$E=\left((P o+k V)+\frac{P o \times t e}{T}+\frac{P_{t}}{T}\right)\left(t_{m}\right)+(P o \times t l)$
$E s=\left((P o+k V)+\frac{P o \times t e}{T s}+\frac{P_{t}}{T s}\right)(t m)+(P o \times t c)$
$E r=\left((P o+k V)+\frac{P o \times t e}{T r_{i}}+\frac{P_{t}}{T r_{i}}\right)(t m)+(P o \times t c)$
$E=E_{s}+\sum_{i=1}^{i=n} E_{r}+(P o \times t p)$

\section{Carbon Emissions}

The optimization model in the research conducted by Li et al. [3] provided total carbon emissions in the machining process of turning consisting of electricity carbon emissions, cutting tool carbon emissions, cutting fluid carbon emissions, material carbon emissions, and spear carbon emissions. The model developed in this research is dry turning condition machining. Therefore, cutting fluid is not required. According to Yi et al. [20], material carbon emissions and carbon emissions only have a minimal effect on machining parameters. Thus, they are not included in the optimization model of carbon emissions.

$C E=C E_{\text {elec }}+C E_{\text {tool }}$

\section{Electricity carbon emissions $\left(C E_{\text {elec }}\right)$}

The amount of carbon emissions of CNC machine that comes from electricity is determined by the amount of the electric carbon emission factor and the total energy consumption during machining process.

$C E_{\text {elec }}=C E F_{\text {elec }} \times E_{\text {total }}$ 
$C E_{\text {elec }}=C E F_{\text {elec }} \times\left(E_{s}+\sum_{i=1}^{i=n} E_{r}+(P o \times t p)\right)$

$C E F_{\text {elec }}$ may vary in each region. This is due to differences in the structure of the electrical network. In this research, the $C E F_{\text {elec }}$ rate is 0,6747 $\mathrm{kgCO}_{2} / \mathrm{kWh}$, in line with the national average of electric carbon emission factors. This $C E F_{\text {elec }}$ data is quoted from the Ministry of National Development and Reform Commission (NDRC) of China.

\section{Cutting tool carbon emissions ( $\left.C E_{\text {tool }}\right)$}

The amount of carbon emission for cutting tools can be obtained by multiplying the ratio of machining time on tool life expectancy with the carbon emission factor of cutting tools and the mass of cutting tools.

$C E_{\text {tool }}=\frac{t m}{T} \times C E F_{\text {tool }} \times W_{\text {tool }}$

$C E F_{\text {tool }}$ is the carbon emission factor of cutting tool and $W_{\text {tool }}$ is the mass of cutting tool. Based on the research conducted by Rajemi and Mativenga [21], on manufacturing process, the carbon emission factor for cutting tool is $29.6 \mathrm{kgCO}_{2} / \mathrm{kg}$.

\section{Total carbon emissions}

The total carbon emissions generated during the manufacturing process are the sum of electricity carbon emissions and cutting tool carbon emissions. Total carbon emissions is formulated as follows

$$
\begin{aligned}
& C E=C E F_{\text {elec }} \times\left(E_{S}+\sum_{i=1}^{i=n} E_{r}+(P o \times t p)\right)+\frac{t m}{T} \times \\
& C E F_{\text {tool }} \times W_{\text {tool }}
\end{aligned}
$$

\section{Noise}

The objective function of noise represents the social aspect of sustainable manufacturing as personal health. Noise must remain on the safe threshold. Thus, it is crucial to develop acceptable machining models. In Cirtu's [12], the noise model is still in the form of single-pass turning. Then, this research will be developed into multi-pass turning.

$$
\begin{aligned}
& N=\sum_{i=1}^{n} N r_{i}+N s \\
& N r_{i}=\sum_{i=1}^{n}\left(a \times P o+b \times\left(\frac{v r_{i}}{f r_{i}}\right)+c \times\left(P o \times\left(\frac{v r_{i}}{f r_{i}}\right)\right)+L m\right) \\
& N s=a \times P o+b \times\left(\frac{v s}{f s}\right)+c \times\left(P o \times\left(\frac{v s}{f s}\right)\right)+L m
\end{aligned}
$$

\section{Production Costs}

According to Chen and Tsai [11], production costs in the machining process of multi-pass CNC turning can be divided into four cost elements, namely machining cost $(\mathrm{Cm})$, idle cost or cost during machine preparation and tool setting $(\mathrm{Cl})$, tool replacement cost $(\mathrm{Ctr})$, and tool wear cost $(C t w)$.

$C=C m+C i+C t r+C t w$

\section{Machining cost}

Machining cost is the result of multiplying direct labor costs and overhead (ko) with machining time (tm).

$C m=k o \times t m$
$C m=k_{0} \times\left(\sum_{i=1}^{i=n} \frac{\pi D L}{1000 r_{i} f r_{i}}+\frac{\pi D L}{1000 v s f s}\right)$

\section{Idle cost}

There are two times of idle time, namely loading and unloading operation constant time and variable time [22]. The idle process occurs during tool preparation and cutting tool settings. The following is the equation for idle machine cost.

$C l=k o \times t l$

$C l=k o \times\left[t p+\left(n\left(h_{1} L+h_{2}\right)+\left(h_{1} L+h_{2}\right)\right]\right.$

\section{Tool replacement cost}

Tool replacement cost is the multiplication of direct labor cost and overhead ( $k o$ ) with the time to replace the tool.

$C t r=k o \times\left(t e\left(t_{m} / T\right)\right)$

Tool wear cost

Tool wear cost is the cost incurred during the tool usage. $k t$ is the cost of each cutting edge.

$C t w=k t \times\left(t_{m} / T\right)$

\section{Total production cost per unit}

The total production cost per unit is the sum of machining cost, idle cost, tool replacement cost, and tool wear cost. The following is the equation for the total production cost.

$$
\begin{aligned}
& C=(k o \times t m)+(k o \times t l)+\left(k o \times t e\left(t_{m} / T\right)\right)+(k t \times \\
& \left.\left(t_{m} / T\right)\right)
\end{aligned}
$$

\section{Constraints}

Constraints in roughing:

Cutting speed in roughing

$v_{\text {rmin }} \leq v_{r} \leq v_{\text {rmax }}$

Depth of cut in roughing.

$f_{r \min } \leq f_{r} \leq f_{\text {rmax }}$

Feed rate in roughing

$a_{\text {prmin }} \leq a_{p r} \leq a_{\text {prmax }}$ 
Cutting force constraint in roughing

$F_{r}=k_{f} f_{r}^{\mu} a p_{r}^{v} \leq F_{\max }$

Cutting power constraint in roughing

$P_{r}=\frac{k_{f} f_{r}^{\mu} a p_{r}^{v} V_{r}}{6000 \eta} \leq P_{\max }$

Chip tool interface temperature constraint

$Q_{r}=k_{q} V_{r}^{\tau} f_{r}^{\phi} d_{r}^{\delta} \leq Q_{u}$

Constraint in surface roughness

$f_{r} \leq \sqrt{\frac{r_{e} R_{r, \max }}{32,1}}$

Constraints in finishing:

Cutting speed in finishing

$v_{\text {smin }} \leq v_{s} \leq v_{\text {smax }}$

Depth of cut in finishing

$f_{\text {smin }} \leq f_{s} \leq f_{\text {smax }}$

Feed rate in finishing

$a_{p \min } \leq a_{p s} \leq a_{p s \max }$

Cutting force constraint in roughing finishing

$F_{s}=k_{f} f_{s}^{\mu} a p_{s}^{v} \leq F_{\max }$

Cutting power constraint in finishing

$P_{S}=\frac{k_{f} f_{s}^{\mu} a p_{s}^{v} V_{s}}{6000 \eta} \leq P_{\text {max }}$

Chip tool interface temperature constraint

$Q_{s}=k_{q} V_{s}^{\tau} f_{s}^{\phi} d_{s}^{\delta} \leq Q_{u}$

Constraint in surface roughness

$f_{s} \leq \sqrt{\frac{r_{e} R_{s, \max }}{32,1}}$

The relation of roughing and finishing parameters

Relation of cutting speed parameters

$v_{s} \geq k_{1} v_{r}$

Relation of feed rate parameters

$f_{r} \geq k_{2} f_{s}$

Relation of depth of cut parameters

$a p_{r} \geq k_{3} a p_{s}$

Total depth of cut

$a p_{t}=a p_{s}+\sum_{i=1}^{i-n} a p_{r}$

\section{Results and Discussions}

\section{Numerical Example and Analysis}

Numerical examples are taken from previous studies with adjustments based on the context of the problem (model) that has been created in this research. The workpiece used in this study has a diameter of $50 \mathrm{~mm}$ and a length of $300 \mathrm{~mm}$. The total depth of the cut is $6 \mathrm{~mm}$. The maximum cutting power is $5 \mathrm{~kW}$, and the maximum cutting force is 1960 Newton. The maximum temperature on the workpiece surface is $1000^{\circ} \mathrm{C}$. The maximum surface roughness in the roughing process is $25 \mu \mathrm{m}$, and the maximum surface
Tabel 2. Parameter value related to energy consumption

\begin{tabular}{ccc}
\hline Notation & Unit & Value \\
\hline $\mathrm{P}_{0}$ & $\mathrm{kWh}$ & 3,594 \\
$\mathrm{P}_{\mathrm{t}}$ & $\mathrm{MJ} /$ insert & 5,3 \\
$\mathrm{te}_{\mathrm{e}}$ & $\mathrm{min} / \mathrm{sisi}$ & 1,5 \\
$\mathrm{t}_{\mathrm{p}}$ & $\mathrm{min} / \mathrm{unit}$ & 0,75 \\
\hline
\end{tabular}

Source: Arif et al. [10]

Table 3. Parameter value related to carbon emission

\begin{tabular}{ccc}
\hline Notation & Unit & Value \\
\hline $\mathrm{CEF}_{\text {elec }}$ & $\mathrm{kgCO}_{2} / \mathrm{kWh}$ & 0,6747 \\
$\mathrm{CEF}_{\text {tool }}$ & $\mathrm{kgCO}_{2} / \mathrm{kWh}$ & 29,6 \\
$\mathrm{~W}_{\text {tool }}$ & $\mathrm{g}$ & 9,5 \\
\hline
\end{tabular}

Source: Li et al. [3]

Table 4. Parameter value related to noise

\begin{tabular}{cr}
\hline Notation & \multicolumn{1}{c}{ Value } \\
\hline$a$ & 0.17 \\
$b$ & $-14 \times 10^{-5}$ \\
$c$ & $0.6 \times 10^{-5}$ \\
Lm & 78.7 \\
\hline Source: Cirtu et al. $[12]$ &
\end{tabular}

Table 5. Parameter value related to cost production

\begin{tabular}{llr}
\hline Notation & Unit & Value \\
\hline $\mathrm{k}_{0}$ & $\$ /$ min & 0,5 \\
$\mathrm{k}_{\mathrm{t}}$ & \$/edge & 2,5 \\
$\mathrm{t}_{\mathrm{e}}$ & min/edge & 1,5 \\
$\mathrm{t}_{\mathrm{p}}$ & min/unit & 0,75 \\
\hline \multicolumn{2}{l}{ Source: Chen and Tsai [11] }
\end{tabular}

Table 6. Parameter value related to constrain function.

\begin{tabular}{lrlr}
\hline Notation & Value & Notation & Value \\
\hline $\mathrm{h}_{1}$ & $7 \times 10^{-4}$ & apr $_{\max }$ & 4 \\
$\mathrm{~h}_{2}$ & 0,3 & apr $_{\min }$ & 1 \\
$\mathrm{k}$ & 5250 & apsmax & 2 \\
$\mathrm{k} 0$ & 0,5 & apsmin & 0,5 \\
$\mathrm{kt}$ & 2,5 & $\mathrm{fr}_{\max }$ & 0,9 \\
$\mathrm{k} 1$ & 1 & $\mathrm{fr}_{\min }$ & 0,1 \\
$\mathrm{k} 2$ & 2,5 & $\mathrm{fS}_{\max }$ & 0,9 \\
$\mathrm{k} 3$ & 1 & $\mathrm{fS}_{\min }$ & 0,1 \\
$\mathrm{kq}$ & 132 & $\mathrm{vr}_{\max }$ & 500 \\
$\mathrm{kf}$ & 108 & $\mathrm{vr}_{\min }$ & 50 \\
$\delta$ & 0,105 & $\mathrm{vS}_{\max }$ & 500 \\
$\phi$ & 0,2 & $\mathrm{vS}_{\min }$ & 50 \\
$\tau$ & 0,4 & $i$ & 2 \\
$\theta$ & 0,5 & $\mathrm{v}$ & 0,95 \\
$\eta$ & 0,8 & & \\
Source: Arif et al. $[10]$ & & &
\end{tabular}

roughness in the finishing process is $2.5 \mu \mathrm{m}$. The mechanical efficiency $(\eta)$ is $85 \%$.

Table 2 -Table 6 exhibit the parameter setting for the numerical analysis.

\section{Result}

The search for the solution of this research model was carried out in two stages, particularly using the Genetic Algorithm method with Matlab R2016b 


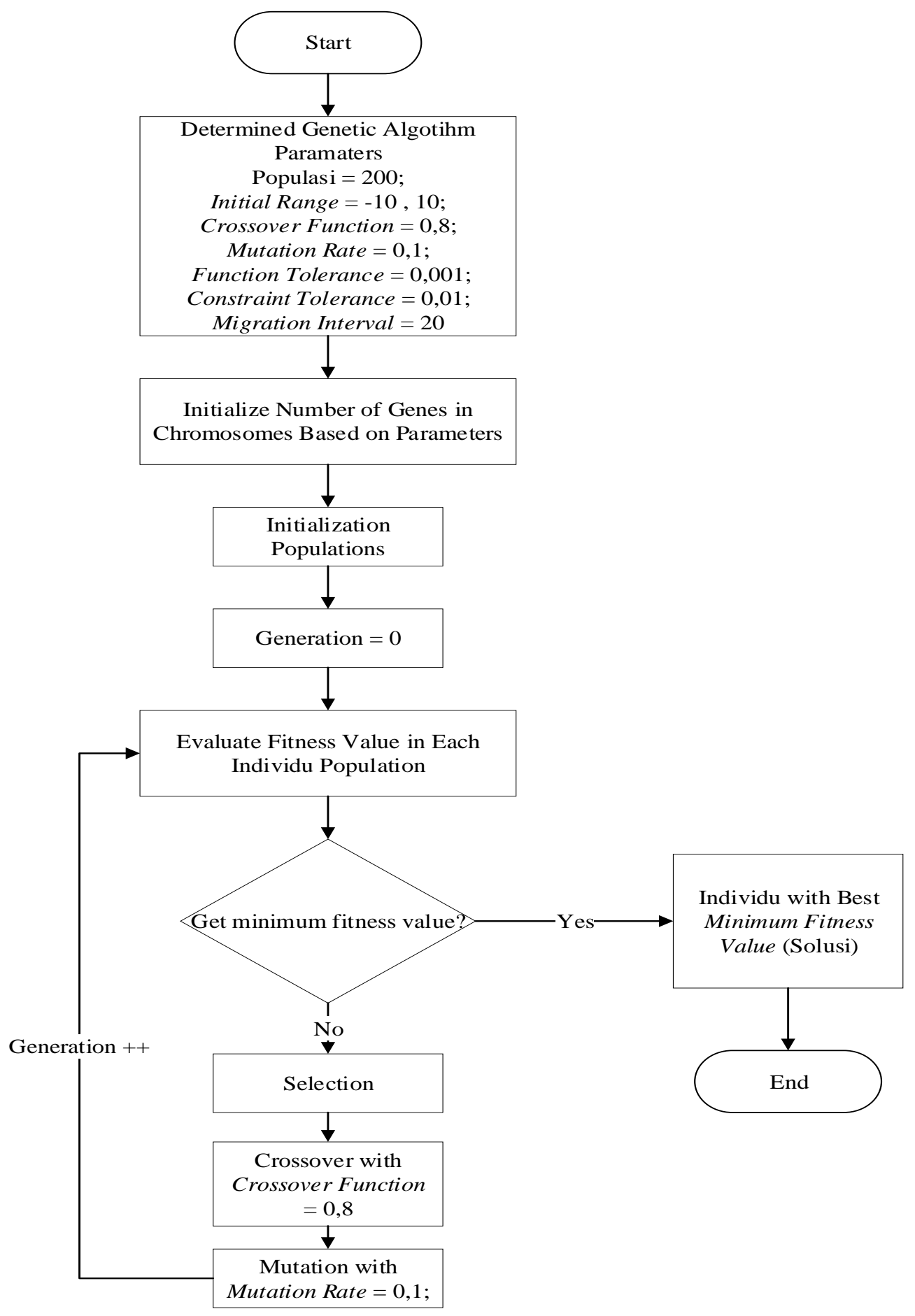

Figure 1. The genetic algortihm schemes

software and using the transformation and weighting functions for each objective function. The Genetic Algorithm is used to determine the feasible solution value of the objective function, namely cost minimization, energy minimization, noise minimization, and carbon emission minimization. The genetic algorithm scheme is depicted in Figure 1. In this research, there are two roughing processes and one finishing process.

Through feasible solution value (see Table 7), the optimal value can be obtained with normalization by using transformation and weighting function procedures. Each objective function has a weighted value of 0.25 according to the importance level of the objective function.

The result of multi-objective optimization shown in (Table 8) with total production cost of $2,19 \$$; total energy consumption is 2,50 $\mathrm{MJ}$; total noise of 236,19 $\mathrm{dB}$; and total carbon emission of $5,97 \mathrm{kgCO}_{2}$. 
Table 7. Feasible minimum and maximum value used for the normalization stage

\begin{tabular}{|c|c|c|c|c|c|c|c|c|}
\hline \multirow{2}{*}{$\begin{array}{l}\text { Decision } \\
\text { Variabel } \\
\end{array}$} & \multicolumn{2}{|c|}{$C_{\text {total }}(\$)$} & \multicolumn{2}{|c|}{$E_{\text {total }}(\mathrm{MJ})$} & \multicolumn{2}{|c|}{$N_{\text {total }}(\mathrm{dB})$} & \multicolumn{2}{|c|}{ CEtotal $\left(\mathrm{kgCO}_{2}\right)$} \\
\hline & Min & Max & Min & $\operatorname{Max}$ & Min & Max & Min & Max \\
\hline$f s$ & 0.28 & 0.10 & 0.29 & 0.11 & 0.11 & 0.27 & 0.15 & 0.11 \\
\hline aps & 0.82 & 1.15 & 1.17 & 1.21 & 1.10 & 1.08 & 0.82 & 0.82 \\
\hline$v s$ & 303.20 & 72.92 & 273.33 & 53.41 & 385.70 & 214.41 & 179.35 & 230.12 \\
\hline$f r_{2}$ & 0.88 & 0.26 & 0.90 & 0.25 & 0.42 & 0.86 & 0.37 & 0.88 \\
\hline $\mathrm{fr}_{3}$ & 0.39 & 0.26 & 0.34 & 0.29 & 0.42 & 0.82 & 0.28 & 0.84 \\
\hline$f r_{4}$ & 0.63 & 0.63 & 0.89 & 0.41 & 0.63 & 0.68 & 0.49 & 0.68 \\
\hline$a p r_{2}$ & 2.63 & 2.41 & 2.44 & 2.48 & 2.47 & 2.55 & 2.61 & 2.64 \\
\hline$a p r_{3}$ & 1.64 & 1.65 & 1.63 & 1.63 & 1.59 & 1.54 & 1.61 & 1.64 \\
\hline$a p r_{4}$ & 1.27 & 1.28 & 1.25 & 1.26 & 1.25 & 1.25 & 1.24 & 1.23 \\
\hline$v r_{2}$ & 82.29 & 53.15 & 70.55 & 51.30 & 95.29 & 61.82 & 60.54 & 130.57 \\
\hline$v r_{3}$ & 61.69 & 55.15 & 79.13 & 55.44 & 111.69 & 70.32 & 75.83 & 77.46 \\
\hline$v r_{4}$ & 167.56 & 167.59 & 75.66 & 70.66 & 79.64 & 79.67 & 57.86 & 103.06 \\
\hline
\end{tabular}

\section{Objective
function}

value $(U)$

$2,137 \quad 9,534 \quad 2,495$

$5,610 \quad 236,161$

$393,667 \quad 3,070$

66,910

Table 8. Optimization result

\begin{tabular}{llr}
\hline Objective function & Unit & Value \\
\hline Production cost & $\$$ & 2.19 \\
Energy consumption & $\mathrm{MJ}$ & 2.50 \\
Noise & $\mathrm{dB}$ & 236.19 \\
Carbon emission & $\mathrm{kgCO} 2$ & 5.97 \\
\hline \multicolumn{2}{c}{ Decision variable } \\
\hline Feed rate in finishing (fs) & $\mathrm{mm} / \mathrm{rev}$ & 0.27 \\
Depth of cut in finishing (aps) & $\mathrm{mm}$ & 0.93 \\
Cutting speed in finishing (vs) & $\mathrm{mm} /$ minute & 308.09 \\
Feed rate in roughing (fr) & $\mathrm{mm} / \mathrm{rev}$ & 0.84 \\
Depth of cut in roughing (apr) & $\mathrm{mm}$ & 2.55 \\
Cutting speed in roughing $(\mathrm{vr})$ & $\mathrm{mm} /$ minute & 78.08 \\
Roughing pass & & 2 \\
Objective function value $(U)$ & & 0.013 \\
\hline
\end{tabular}

Table 9. Sets of parameters

\begin{tabular}{cl}
\hline Control parameter & Values \\
\hline$f r_{1}$ & {$[0,84 ; 1,48 ; 2,11 ; 2,74 ; 3,37]$} \\
$f r_{2}$ & {$[0,84 ; 1,48 ; 2,11 ; 2,74 ; 3,37]$} \\
$f s$ & {$[0,27 ; 0,47 ; 0,54 ; 0,67 ; 0,74]$} \\
$v r_{1}$ & {$[78,08 ; 136,64 ; 195,20 ; 253,76 ; 312,32]$} \\
$v r_{2}$ & {$[78,08 ; 136,64 ; 195,20 ; 253,76 ; 312,32]$} \\
$v s$ & {$[308,09 ; \quad 539,17 ; \quad 616,19 ; \quad 770,24 ;$} \\
& $781,95]$ \\
$a p r_{1}$ & {$[2,55 ; 2,45 ; 2,35 ; 2,25 ; 2,15]$} \\
$a p r_{2}$ & {$[2,55 ; 2,45 ; 2,35 ; 2,25 ; 2,15]$} \\
$a p s$ & {$[0,93 ; 0,83 ; 0,74 ; 0,65 ; 0,56]$} \\
\hline
\end{tabular}

\section{Sensitivity Analysis}

The purpose of the sensitivity analysis in this research is to show the behaviour of the model parameters in some model parameters, namely feed rate in roughing process $\left(\mathrm{fr}_{1}\right)$, feed rate in finishing process (fs), cutting speed in roughing $\left(\mathrm{vr}_{1}\right)$, and the cutting speed in finishing (vs). All of the machining parameters are chosen as the decision variables, and $n$ equal to 2 . Various experiment sets were designed for analysis. All experiment are shown in Table 9.

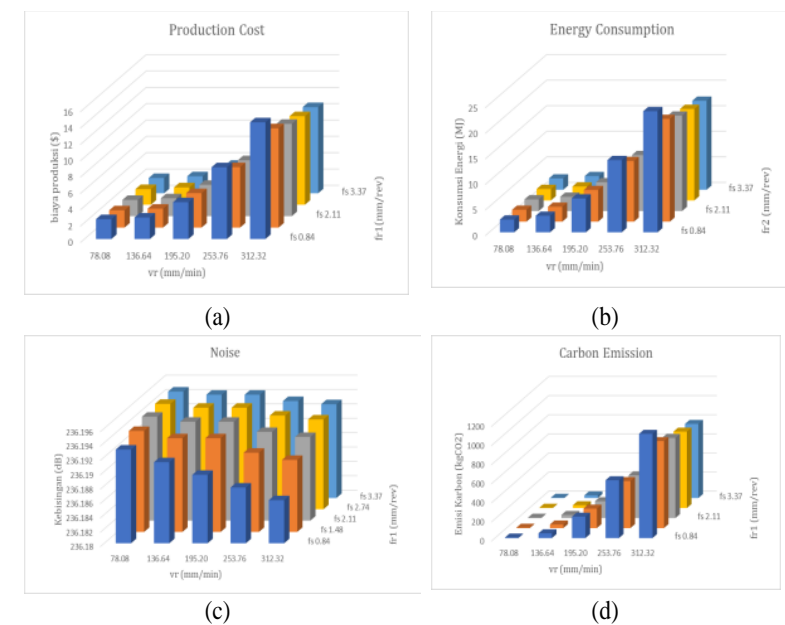

Figure 2 The Effect of Changes in $f r$ dan vr Parameters on (a) Production Cost, (b) Energy Consumption, (c) Noise and (d) Carbon Emission

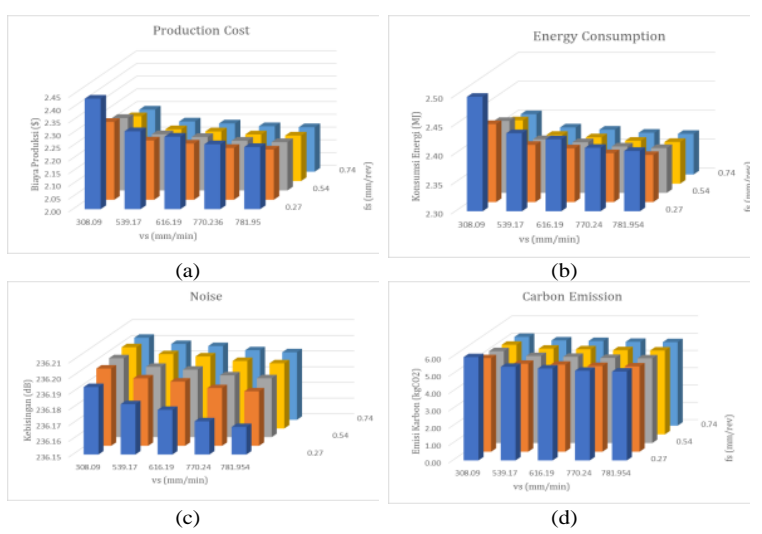

Figure 3 The Effect of Changes in $f s$ dan vs Parameters on (a) Production Cost, (b) Energy Consumption, (c) Noise and (d) Carbon Emission

Figure 2 and Figure 3 exhibit the sensitivity analysis of the cutting speed in roughing and the configuration of the feed rate consecutively. The energy 


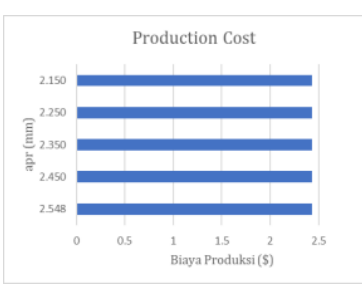

(a)

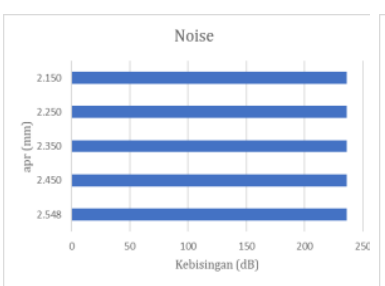

(c) (b)

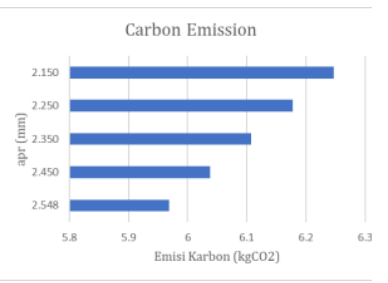

(d)

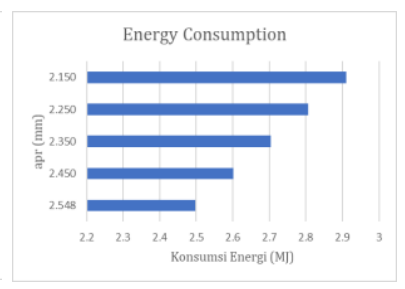

Figure 4 The Effect of Changes in apr dan aps Parameters on (a) Production Cost, (b) Energy Consumption, (c) Noise and (d) Carbon Emission

consumption, production costs, and carbon emissions increase when the feed rate and cutting speed in roughing process increase. However, in the noise objective function, changes in the feed rate and cutting speed of the roughing process do not significantly affect the noise value.

When the parameter values in the finishing process increase, the value of energy consumption, production costs, and carbon emissions will decrease, meanwhile, the noise objective function is not significantly affected by changes in the finishing feed rate parameters and finishing cutting speed.

From figure 4, it can be seen that changes in the depth of cut parameter have only a small effect on the results of the three objective functions (production costs, carbon emissions, and noise). In the energy consumption objective function, the value increases when the feed rate in roughing process parameter is increased. The value of the carbon emission objective function increases slightly when the feed rate in roughing process parameter is increased.

It can be inferred that changes in parameters are sensitive to the three objective functions. Conversely, the noise objective function is insensitive to changes in parameters. This is because the machining parameters only have a minimal effect on the value of the noise objective function. Meanwhile, in the other three objective functions, machining parameters have a big influence. Thus, optimizing the machining parameters is necessary to minimize the level of carbon emission, energy consumption, and high production cost. Based on the sensitivity analysis results, the machining parameters can affect the four objective functions. The manufacturing industry must keep attention to the use or choice of machining parameters to support sustainable manufacturing.

\section{Conclusion}

This research produces a multi-objective optimization model that can optimize machining parameters to minimize production cost, energy consumption, noise, and carbon emission. The machining parameters considered in this research are cutting speed, depth of cut, and feed rate in each roughing and finishing process. This research is the optimal value of each machining parameter. The total energy consumption value obtained is $2.50 \mathrm{MJ}$; total production cost is $\$$ 219; total carbon emissions are $5.97 \mathrm{kgCO} 2$, and noise is $236.19 \mathrm{~dB}$.

Based on the sensitivity analysis results, the machining parameters that affect the objective function are the cutting speed parameter and feed rate parameter. However, changes in machining parameters do not have a significant effect on the noise objective function. This research can be improved in various directions. Further research can add tool wear conditions. Thus, it can be adjusted to a real CNC turning system.

\section{References}

1. Zhang, L., Zhang, B., Bao, H., and Huang, H. Optimization of Cutting Parameter for Minimizing Environmental Impact: Considering Energy Efficiency, Noise Emission and Economic Dimension. International Journal of Precision Engineering and Manufacturing, 19(4), 2018, pp. 613-624.

2. Zhao, Y., Ke, J., Ni, C.C., McNeil, M., Khanna, N.Z., Zhou, N., Fridley, D., and Li, Q. A Comparative Study of Energy Consumption and Efficiency of Japanese and Chinese Manufacturing Industry, Energy Policy, 70, 2014, pp. 4555.

3. Li, C., Tang, Y., Cui, L., and Li, P. A Quantitative Approach to Analyze Carbon Emissions of CNC Based Machining System, J Intell Manuf, 2013.

4. United Nations. Kyoto Protocol to the United Nations Framework Convention. On Climate Change, 1998, Kyoto.

5. Lu, T., Gupta, A., Jayal, D., Badurdeen, F., Feng, S. C., Dillon, O. W., and Jawahir, I. S. A Framework of Product and Process Metrics for Sustainable Manufacturing, Global Conference on Sustainable Manufacturing, Geithsburg, Springer, 2011, pp. 333-338.

6. Wang, Q., Liu, F., and Wang, X. Multi-Objective Optimization of Machining Parameters Considering Energy Consumption. International 
Journal of Advance Manufactruing Technology, 2013, pp. 1133-1142.

7. Bagaber, S. A., and Yusoff, A. R. Energy and Cost Integration for Multi-Objective Optimisation In A Sustainable Turning Process. Measurement, 2019, pp. 795-810.

8. Lin, W., Yu, D.Y., Zhang, C., Liu, X., Zhang., S., Tian, Y., Liu, S., and Xie, Z. A Multi-Objective Teaching-Learning-Based-Optimizatio Algorithm to Scheduling in Turning Processes for Minimizing Makespan and Carbon Footprint. Journal of Cleaner Production, 2015, pp 1- 46.

9. Jiang, Z., Gao, D., Lu, Y., and Liu, Xianli. Optimization of Cutting Parameters for Trade-off Amog Carbon Emissions, Surface Roughness, and Processing Time. Chinese Journal of Mechanical Engineering, 32:94, 2019, pp 1-18.

10. Arif, M., Stroud, I. A., and Akten, O. A Model to Determine the Optimal Parameter for Sustainable-Energy Machining in Multi-Pass Turning Operation. Journal Engineering Manufacture, 228(6), 2013, pp. 866-877.

11. Chen, M. C., and Tsai, D. M. A Simulated Annealing Approach for Optimization of MultiPass Turning Operation, International Journal of Production Research, 34(10), 1996, pp. 2803-2825.

12. Cirtu, N. D., Dimitriu, R., D Hartley., and Golder A. A., Survey of the Noise Levels of Metal-cutting Machine Tools, Proceedings of the Sixteenth International Machine Tool Design and Research Conference, 1976, pp. 363-269.

13. Whitley, D. A Genetic Algoritm Tutorial. Statistics and Computing, 1994, pp. 65-85.
14. Mawaddah, N. K., and Mahmudy, W. F.Optimasi Penjadwalan Ujian Menggunakan Algoritma Genetika, Kursor, 2016, pp. 1-8.

15. Marler, R.T., Arora, J.S. Survey of MultiObjective Optimization Methods for Engineering. Structural and Multidisciplinary Optimization, 26, 2004, pp. 369-395.

16. Marler, R.T., Arora, J.S. The Weighted Sum Method for Multi-Objective Optimization: New Insights, Structural and Multidisciplinary Optimization, 41, 2010, pp. 853-862.

17. Addona, D. A., and Teti, R. Genetic Algorithm Based Optimization of Cutting Parameters in Turning Processes. Procedia CRIP (7), 2013, pp. 323-328.

18. Tian, C., Zhou, G., Zhang, J., and Zhang, C. Optimizaton of Cutting Parameters Considering Tool Wear Conditions in Low-Carbon Manufacturing Environment. Journal of Cleaner Production, 2019, pp. 706-719.

19. Shaw M.C. Metal Cutting Principle, Oxford: Clarendon Press, 1984.

20. Yi, Q., Li, C., Tang, Y., \& Chen, X. Multi-Objective Paramete Optimization of CNC Machining for Low Carbon Manufacturing. Journal of Cleaner Production, 2015, 1-9.

21. Rajemi, M. F., Mativenga, P. T., and Aramcharoen, A. Sustainable Machining: Selection of Optimum Turning Conditions Based on Minimum Energy Considerations. Journal of Cleaner Production, 18(10-11), 2010, 1059-1065.

22. Shin Y.C. and Joo, Y. S., Optimization of Machining Conditions with Practical Constraints, International Journal of Production Research, 30, 1992, pp. 2907-2919. 